\title{
Truth-Claiming in Fiction
}

\author{
Towards a Poetics of Literary Assertion
}

Jukka Mikkonen

\begin{abstract}
In the contemporary analytic philosophy of literature and especially literary theory, the paradigmatic way of understanding the beliefs and attitudes expressed in works of literary narrative fiction is to attribute them to an implied author, an entity which the literary critic Wayne C. Booth introduced in his influential study The Rhetoric of Fiction. The aim of this paper is to suggest that although the implied author sheds light on certain type of literary narratives, it is insufficient in a so-called conversational interpretation, which emphasizes the truth-claims conveyed by a fiction. In my paper, I shall show that, first, from an ontological point of view, truth-claims or actual assertions in fiction, if any, have to be attributed to the actual author and, second, that the question of truth-claiming in and by fiction is an epistemological matter concerning the actual intentions of the author.

KEYWORDS Literature, fiction, interpretation, implied author, actual author, truth-claiming
\end{abstract}

\section{Introduction}

"Literary criticism often invents authors: It will take two dissimilar works - the Tao Te Ching and the 1001 Nights, for instance - attribute them to a single author, and then in all good conscience determine the psychology of that most interesting homme de lettres..." -Jorge Luis Borges, "Tlön, Uqbar, Orbis Tertius".

In the contemporary analytic philosophy of literature and especially literary theory, the paradigmatic way of understanding the beliefs and attitudes expressed in works of literary narrative fiction is to attribute them to an implied author, an entity which the literary critic Wayne C. Booth introduced in his influential study The Rhetoric of Fiction. Roughly put, the implied author is an entity between the actual author and the narrator whose beliefs and attitudes cannot be appropriately ascribed to the actual author. Over the decades, this the author's second self, a construct the actual author is seen to create in her act of writing, has gained an established place in literary theory. In the philosophy of literature, in turn, the implied author has evolved into multiple entities; it has been represented and developed as, for instance, the postulated author (Alexander Nehamas), the fictional author (Gregory Currie) and the model author (Umberto Eco).

In general, the implied author is a workable concept in literary interpretation. As the implied author is embedded in the work and can 
be derived solely from it, her views help to understand certain types of narratives. Nonetheless, the implied author is an inadequate authorial concept when studying certain social functions of literature. Now, there are works and even sub-genres of fiction in which truth-claims about, say, moral, political, historical and philosophical issues have a focal role in understanding the work appropriately. Conveying genuine messages and changing readers' beliefs through fiction are widely acknowledged and central functions of the literary practice. The problem is, however, that the implied author, as generally understood as a fictional entity, cannot be the locus of genuine beliefs. ${ }^{2}$

The aim of this paper is to suggest that although the implied author, and its philosophical counterparts, sheds light on certain types of narratives, it is insufficient in approaches which emphasize the truth-claims conveyed by a work. In what follows, I shall show that, first, from an ontological point of view, truth-claims or actual assertions in literary fiction, if any, have to be attributed to the actual author and, second, that the question of truth-claiming in and by literary fiction is an epistemological matter concerning the actual intentions of the author.

\section{The Voice behind the Lines}

Wayne C. Booth's Rhetoric of Fiction, originally published in 1961 and revised in 1983, has had an enormous effect on literary criticism and the philosophy of literature, especially the Anglo-American analytic tradition. In his study, Booth proposed a middle course between the New Critics who denied the relevance of the actual author's intentions in literary interpretation and biographical critics who argued that a literary work should be understood in the light of the life of its author. Booth argued against the New Critics by claiming that one cannot talk about a text without talking about the author, for a text implies its author's existence. However, Booth also wanted to distance himself from biographical criticism which he considered rather unscientific; as he saw it, the actual author's intentions (that is, her beliefs and attitudes) and her values and feelings cannot ever be known. To navigate between these two interpretative practices, Booth introduced the implied author, who "chooses, consciously or unconsciously, what we read; we infer him as an ideal, literary, created version of the real man; he is the sum of his own choices."

In general, it has been thought that what basically creates the implied author is the author's literary-fictive mode of speaking. For Booth, for instance, the implied author primarily consists of the author's style, tone and technique. Nevertheless, Booth maintains that the implied author 
is not only a product which the author intentionally creates but also a construction made by the reader about the author based on the work. ${ }^{4}$ According to him, it does not matter how impersonal the author may try to be, for her readers will inevitably construct the implied author. As Booth sees it, readers need to postulate the implied author, for their reactions to the implied author's "various commitments, secret or overt" help to determine their response to the work. For him, readers' sense of the implied author includes the meanings extracted from the work and also the moral and emotional content of events portrayed in the work. ${ }^{5}$

Moreover, Booth argues that the implied author is work-bound and that the author's different works will imply different versions of the implied author. As he sees it, the differences become evident when the implied author is given "an overt, speaking role in the story." Elsewhere, Booth also speaks of a career author, a person construct which consists of implied authors of works published under the same author name. He defines the career author as "a cumulative character whom we infer as we read a second or third tale told by what we call the 'same' teller" and "who is the sum of various inferred characters." According to Booth, the career author is the character "implied by the writing of a sequence of works." However, Booth also argues that the career author is distinct from the actual author. He claims that "no matter how many tales [the author] tells, an immense proportion of what he believed, did, or said will never appear in his fictions."

In analytic philosophy of literature, Booth's theory of the implied author has been developed especially by so-called hypothetical intentionalists who consider the meaning of a literary work as an assumption of either the actual author's or of an hypothetical or postulated author's intended meaning by referring to the beliefs and expectations of the author's intended, ideal or appropriate audience. ${ }^{8}$ To mention some, Alexander Nehamas suggests in his theory of the postulated author, which he also refers to as "the author figure," that while a literary work is interpreted and understood as its author's production, its author is not identical with the historical author. Instead, Nehamas argues, the author of a literary work is "postulated as the agent whose actions account for the text's features; he is a character, a hypothesis which is accepted provisionally, guides interpretation, and is in turn modified in its light."10 According to Nehamas, the author is not a person but a construction produced "jointly by writer and text, by work and critic"; she is "a plausible historical variant of the writer, a character the writer could have been, someone who means what the writer could have meant, but never, in any sense, did mean."11 Akin to Nehamas, Jenefer M. Robinson suggests 
that it is a convention of the literary practice that the author more or less consciously adopts a persona and that she is not trying to deceive her audience into believing that this assumed persona is her own. As Robinson sees it, the author's persona, her style, is an expression of the personality she seems to have: the author's style consists of, for instance, her way of treating the subject and the theme of the work. ${ }^{12}$

A focal reason for the attractiveness of the implied author theory has had is, as P. D. Juhl puts it, that the implied author is completely incorporated in a work and hence can be grasped from it. ${ }^{13}$ Further, as a Boothian autonomous collection of beliefs and norms, the implied author makes it possible to distinguish between the narrator's beliefs and the author's beliefs which, in turn, prepares the way for, say, identifying an unreliable narrator. In spite of its merits, the implied author does not, nonetheless, stretch wide enough to explain literary communication acts.

\section{An Ontological Approach to Truth-Claiming in Fiction}

Literary fictions have other social functions in addition to their essential aesthetic function. Literary fictions, as other artworks, do not "merely" treat issues important in life; they also convey genuine messages about, say, philosophical issues. To mention some, it is generally believed that Tolstoy's War and Peace includes Leo Tolstoy's thoughts on the philosophy of history; that Sartre's works such as Nausea and No Exit are literary manifestations of Jean-Paul Sartre's existentialist philosophy; that Murdoch's The Black Prince is Iris Murdoch's moral philosophic investigation. Here, intentionalist oriented cognitivists maintain that because literary art is human action, assertions put forward in literary fictions should be examined as actual authors' assertions.

In turn, so-called anti-cognitivist theorists suggest that the points literary fictions seem to convey cannot be attributed to actual authors because of the artistic nature of the works. Anti-cognitivist views which accentuate the relevance of the implied author in literary interpretation generally connect to Austinian/Searlean and Gricean based theories of fiction. These theories suggest that the conventions of fictive story-telling invite the reader to respond to assertion-looking sentences in fiction as being uttered by a fictional speaker and be made-believe instead of assessed as true or false. The theories also maintain that because of the author's fictive mode of speaking, which postulates the implied author and the narrator, there is no bond between the author and the assertions in the work; rather, beliefs a fiction seems to express or imply are to be attributed to its implied author. ${ }^{14}$ 
It is difficult to see how the author's fictive mode of speaking could actually forestall her act of truth-claiming. Given that there are assertions made in and by literary fictions, the assertions have to be attributed to actual authors, for only human agents may make genuine assertions. Naturally, one may also attribute beliefs and truth-claims expressed in a work of fiction to an implied author, but in such case the realm of the beliefs and truth-claims remains fictional: they belong to the same fictitious world of the work as the implied author herself.

When talking about the truth-claims embedded in Tolstoy's War and Peace in his Art and Philosophy published in 1980, Joseph Margolis makes a typical distinction between the author's assertions and the fictional speaker's assertions. Margolis suggests that a characteristically fictional work, a novel, for instance, that seems to convey truth-claims may require the reader to make a distinction between the utterances of $a$ fictional voice, generally the narrator of the work, and those of the actual author. Nevertheless, Margolis does not maintain such an austere distinction but suggests that maybe the reader should take the fictional voice to be what the author wants to predicate as true of the actual world. ${ }^{15}$ As Margolis suggests, a fiction can be said to make claims or reference only if the claims and references are construed as the actual author's claims and references. Hence, while a fictional speaker cannot perform genuine acts, the author may generate genuine acts by her fictive utterances, for instance, by representing the fictional speaker's assertions.

In turn, Noël Carroll suggests that literary interpretation is "roughly analogous" with the interpretation of everyday conversation: the relation between the actual reader and the actual author is similar to that of a hearer and a speaker, for both the reader and the hearer are trying to grasp their conversational partner's intended meaning. ${ }^{16}$ Now, Carroll suggests that when looking for truth-claims made in a literary work, one should pay attention not only to "non-fictional" parts that seem to be uttered by the actual author but also to the ways the represented illocutionary actions, such as characters' assertions, are used by the author to generate genuine illocutionary actions. As Carroll sees it, one should examine what the role of a character is in the context of the work and what the author's aim is in representing her actions. ${ }^{17}$ Conversely, Jerrold Levinson, a paradigmatic hypothetical intentionalist, objects to Carroll's proposal by claiming that, first, passages in literary works which Carroll labels non-fictional must logically be attributed to an implied speaker or a (Beardsleyan-type) narrator because they are put forward by a fictional character, who, unlike the author, belongs to the fictional world of the 
work and reports its events (which she believes in). Second, Levinson argues that one should not divide a literary work into two parts, the author's assertions and the fictional story, for such a distinction would dismiss the "artistic integrity" of the work and make it something which is neither fiction nor non-fiction. ${ }^{18}$

Here, I would like to develop the conversational approach initiated by Carroll. As I see it, Levinson's argument does not, nonetheless, threaten the conversational approach, for, first, the ontological difference between the actual author and the implied author is for the former in the act of truth-claiming. Although it is true, as Levinson suggests, that actual authors do not believe in fictional characters and events their works contain, it is also true that fictional characters, such as implied authors, cannot make actual assertions. Second, the conversational approach does not need to divide a literary work into a fictional story and passages genuinely asserted by the author. In the conversational approach, it may be suggested that conventions of the literary institution determine readers' fictive stance towards the propositions expressed in works of (fictional) literature. Carroll, for instance, maintains that readers should attribute the assertions expressed in a literary fiction primarily to the fictional speaker in question; what he argues is that the assertions may be considered in the second place as the actual author's assertions: the conversational approach aims at examining, for instance, what would be the role of the characters' fictional assertions in the author's overall assertion act.

\section{Reaching the Author}

The most testing problem in the conversational approach is that literary fictions may seem to express beliefs which cannot be ascribed to the actual author; rather, such fictional beliefs can only be appropriately attributed to the implied author. After all, literature is a form of art, and the actual author does not have to hold the beliefs her fictional work seems to put forward. For instance, it is possible that philosophical points a literary fiction seems to suggest are "mere" constituents of the work's theme. Sometimes it may also be difficult to distinguish the claims the reader has constructed from the work from those actually asserted by the author. The problem of truth-claiming in literary fiction is, thus, that only the actual author may make claims but a work may seem to convey claims which cannot be attributed to the actual author. ${ }^{19}$

As suggested in the beginning of the paper, a focal reason for the attractiveness of the implied author theory is that it proposes an easy way 
to norms that govern the narrative structure of the work. For instance, Gregory Currie, a hypothetical intentionalist, suggests in his theory of fiction that the implied author, or the fictional author, is a fictional character who is constructed in the act of make-believe and is taken to be telling the story as known fact. For Currie, reading is an exploration of the implied author's belief structure, whereas the belief set of the implied author consists of the propositions she believes. ${ }^{20}$ Conversely, it has been argued that actual intentionalist approaches may never succeed, for intentions, considered as beliefs and attitudes, are private mental events.

However, such an argument threatens only absolute intentionalist views which maintain that the meaning of a literary work is what the actual author intended it to mean (and which thus run into problems in cases where there is a difference between the conventional textual meaning of the work and the author's intended meaning). Admittedly, absolute intentionalism is a mistaken view, because it takes literary works to mean just whatever their authors choose them to mean. Nevertheless, moderate actual intentionalism, an interpretative practice proposed in different forms in the 1990 s by philosophers such as Carroll, Gary Iseminger, Robert Stecker and Paisley Livingston, maintains that the author's intentions can be grasped through her work because they manifest themselves in the work. Moderate actual intentionalism suggests that the utterance meaning of the work guides the reader to the author's intended meaning. It maintains that while there is no direct access to the author's intentions proper, her intentions are generally recoverable from her work, the context of the utterance and our information about her. ${ }^{21}$

Since the publication of Booth's study, many have suggested that the talk about the implied author is often just a way to sidestep talk about the actual author. It has been noted that different sorts of fictional authors are often actually concealed actual authors as they are, for instance, defined or referred to through the actual author. For example, Daniel O. Nathan suggests that William Tolhurst's hypothetical intentionalism actually depends upon actual intentionalism, for it refers to the actual author's intended audience. ${ }^{22}$ The same can be said of Levinson's hypothetical intentionalism, for it also refers to the actual author's ideal or appropriate audience. In turn, Nehamas's postulated author, or "historically plausible author," ${ }^{23}$ is said to look very much like the actual author from whom he wants to distinguish his author construct. Now, as Robert Stecker puts it, the talk of the postulated author is in many occasions "directly translatable" into talk of hypotheses about the actual author. ${ }^{24}$ Similarly, Saam Trivedi, a "moderate hypothetical intentionalist," as he 
classifies himself, suggests that if one is to look for the communication a literary work attends to, then one should look for the actual author and her communicative intentions. ${ }^{25}$

Here, it is important to note that there are, roughly, two brands of hypothetical intentionalism which can be called actual author hypothetical intentionalism and postulated author hypothetical intentionalism. The first difference between these theories is ontological. Actual author hypothetical intentionalism argues that authors are not fictional but that their intended meanings are; Tolhurst, Levinson and Trivedi, to mention some, support this view. In turn, postulated author hypothetical intentionalism suggests that literary interpretation should not make assumptions about the actual author's intended meaning but that it should rather postulate an author construct to whom the beliefs expressed in the work are attributed; theorists such as Nehamas, Currie and Robinson argue for this view. Second, actual author hypothetical intentionalism and postulated author hypothetical intentionalism are also seen to differ epistemologically. Paisley Livingston and Sherri Irvin suggest that the actual author hypothetical intentionalism and the postulated author hypothetical intentionalism differ in that actual author hypothetical intentionalism may also make use of the author's public biography in producing hypotheses (but not assessing other hypotheses true or false), whereas the postulated author hypothetical intentionalism constructs the author and her intentions from the work only. ${ }^{26}$

In turn, the difference between moderate actual intentionalism and moderate hypothetical intentionalism (or actual author hypothetical intentionalism) might look even vaguer, because both interpretative strategies make hypotheses and assumptions about the actual author's intentions. One difference between the approaches is that moderate hypothetical intentionalism bases its hypotheses on the actual author's ideal audience, emphasizing that the literary utterance meaning of the work is constrained by, say, prevailing literary conventions and the common beliefs of the period the work was composed, whereas moderate actual intentionalism also takes into account the author's actual intentions. Further, moderate hypothetical intentionalism does not allow the author to assess an interpretation considered plausible by interpreters as true or false, whereas moderate actual intentionalism welcomes references to the author's declarations of intention in its search for the meaning of the work. Hence, what makes moderate hypothetical intentionalism hypothetical is that it stagnates at hypotheses even in cases where there is information about the author's actual aims and beliefs. 
Here, I would like to propose a few fresh arguments in support of moderate actual intentionalism, or rather two reasons why moderate actual intentionalism should be preferred to hypothetical intentionalism. As I see it, there are two major problems in hypothetical intentionalism when examining the conversational function of literature: ${ }^{27}$ first, what are interpreters to do with equally plausible hypotheses which hypothetical intentionalist approaches produce, and second, how are interpreters to distinguish between the meaning of a work and its significance or uses $?^{28}$ To begin with, hypothetical intentionalism maintains that where there is room for choice, say, when two hypotheses are equal in their epistemological plausibility, interpreters should choose the construal which makes the work "artistically better." ${ }^{29}$ However, if the interpreter is to determine the truth-claims made in or by a work, she really should not take the work meaning to be the artistically most valuable hypothesis. Instead, the interpreter should look for the actual author's intended meaning. And if there are several interpretations of the literary utterance meaning which are equal in their epistemological plausibility, moderate intentionalism may solve the debate about the correct, or most plausible, interpretation by referring to the actual aims the author has expressed elsewhere.

Furthermore, as noted above, hypothetical intentionalism also allows anachronistic interpretations if they enhance the artistic value of the work. Nevertheless, when determining the truth-claims a literary fiction makes, interpreters should by no means allow an interpretation that the actual author could not have made. An interpretation of the philosophical meaning of Sartre's Nausea is the meaning given by its historical author. On the other hand, an interpretation of Nausea that aims, for example, at shedding light on a contemporary philosophical issue, ascribes significance to the work, not meaning. The latter, creative interpretation is not philosophically less important; it just does not aim at recovering the (intended) philosophical meaning of the work. ${ }^{30}$

\section{The Implied Author as the Author's Style}

Even if one accepts the thesis that only the actual author may be the locus of genuine beliefs and attitudes, a question still remains: what is the need, role and function of the implied author in interpretation? In literary criticism, the concept of the implied author might prove usable, for it allows the talk of, say, the beliefs, attitudes and values the author of the work seems to have without reference to anything outside the work. In turn, when investigating philosophical fictions and other artworks 
that have conversational aims, it might be reasonable to take the implied author rather as the actual author's narrative device, that is, the way she expresses her beliefs.

My proposal concerning the role and function of the implied author in the conversational approach is based on the suggestion which the literary critic Uri Margolin makes in his essay "Cognitive Sciences and the Representation of the Mind in Literary Narrative" (2003). As Margolin sees it, the implied author could be explicated by the notion of the actual author's "cognitive style," 31 which in cognitive science generally describes the way people think, perceive and remember information. One should, however, note that in his article Margolin is investigating literary narratives from the viewpoint of cognitive sciences, and his idea is applied here rather figuratively.

Booth's late writings also support an understanding of the implied author as a means rather than the end of an interpretation. In his article "Resurrection of the Implied Author: Why Bother?" (2005), Booth suggests that actual authors create implied authors like people create masks, favourable versions of themselves, in their everyday life. Furthermore, Booth implies that all writing, for example, the production of scientific works, creates implied authors. ${ }^{32}$ In his account, the implied author is simply a picture of the author as she wants her readers to see her. Actually, as Booth flattens the concept of the implied author by claiming that it relates to all sorts of writing, the concept becomes something very close to the concept of style from which it was developed. ${ }^{33}$

Let us consider, for instance, personae autobiographies are thought to project. In literary criticism it has been suggested that the genre conventions of autobiography allow the author to prettify her past; that the readers will not take autobiographies as neutral and all-inclusive factstating discourse. Following Booth's suggestion, one could say that in writing an autobiography, the actual author creates an implied author which differs from the actual author in certain respects. Here, I suggest that one brings into mind friar Ockham's lex parsimoniae: in the case of the author of an autobiography who prettifies her past, there is no need to say that the actual author creates a favourable author construct that narrates the events; more like, one should say that the actual author chooses facts, leaves out some issues or perhaps even lies. Another example: philosophical studies may embody aggravations, back-pedalled statements and the like. A view a philosopher might characterize "nonsensical" for her colleague becomes "difficult to grasp" when she writes a philosophical paper following the principle of charity, for instance. As I 
see it, one does not need to postulate an implied author for a philosophical paper in interpretation. Instead, I think that one should speak about the actual author's style governed both by discursive conventions regulated by the institution and especially her personal views concerning communication of information and style of argumentation.

What about philosophical fiction, then? What is the role of the implied author in interpreting truth-claims literary fictions such as Sartre's Nausea and No Exit convey? I propose that the implied author may have a role in understanding the work; it can be used as a narrative strategy, for instance, in illustrating a certain kind of way to see the world. Further, the actual author may, say, emphasize or exaggerate her philosophical claims by using a certain type of implied author, that is, style. ${ }^{34}$ Moreover, I find it difficult to grasp how, for example, the actual author's insincerity, her aim to picture herself as more favourable (or unfavourable) than she actually is, would affect the general philosophical views she makes through her work. If one takes Sartre to give a favourable picture of himself in his literary works, does this affect, for instance, the philosophical content of illustrations of existential angst in the works? No, it does not. Thus, I argue that the implied author is best considered a narrative device related to the author's literary assertion act.

As noted in the beginning of the paper, it has also been suggested that because the implied author is constructed from the work, every work embodies an individual implied author. There is nothing peculiar in that. Authors write different sorts of works which project different sorts of pictures of their makers. However, it is not reasonable to maintain that the author who makes genuine illocutionary acts in and by her work should be considered completely work-bound. Let us again consider an analogy in philosophy. Philosophical beliefs are admittedly in a certain sense work-bound: philosophers often change their minds and develop and modify their views; Tractatus and Philosophical Investigations project different pictures of Wittgenstein. As I see it, instead of saying that these works postulate different authors, it would be more apt to say that the author's beliefs expressed in these works, and styles used to express them, differ. And as in Wittgenstein's case, when examining the philosophical views Sartre conveys by his literary works, an interpreter should not construct the author of these philosophical views ex nihilo, novel by novel and play by play, but consider them as the actual author's prevailing views.

In a lecture given in 1966, entitled "Mon expérience d'écrivain," Simone de Beauvoir says that her essays and novels are said to project 
different sorts of pictures of the author, and that the essayist-Beauvoir has been said to be more poignant. Nonetheless, Beauvoir thinks that the Beauvoir derived from her essays and the Beauvoir derived from her novels are not different Beauvoirs. Rather, she says that for her, essays and novels are devices for different sorts of philosophical activities. Furthermore, Beauvoir says that she writes essays when she wants to put forward worked-out theses, whereas she uses novels for expressing ideas that might not be completely structured yet. ${ }^{35}$

\section{Conclusions}

In this paper, I have argued that literary fictions convey truth-claims and that these truth-claims cannot be ontologically ascribed to the implied author, who is a fictional entity. Instead, I have argued that the truthclaims are to be attributed to the actual author of the work. I have argued that there is a suitable theory for interpreting the actual author's communicative act made through a fiction: moderate actual intentionalism which argues that the author's intentions manifest themselves in the work. Further, I have suggested that because moderate actual intentionalism looks for the author's actual intentions and takes them into account in interpretation, this theory of interpretation is far more fitting than hypothetical intentionalism: moderate actual intentionalism aspires to reach the author's actual intentions and uses them as criteria in unravelling the best interpretation of her work. Finally, I have argued that in the conversational approach, a type of interpretation which aims at solving the truthclaims made in a literary fiction, the implied author should be considered the author's style or narrative device. I have suggested that in literary culture, authors are free to project any sort of (author constructions having any sort of) beliefs; that they are free to adopt literary personae in the act of writing. However, I have argued that the conversational approach is in such cases interested in the question of why the actual author has produced such kinds of works and adopted such a person.

\section{Notes}

I would like to thank Arto 'entia non sunt multiplicanda praeter necessitatem' Haapala for providing me the initial idea for this paper.

1. Jorge Luis Borges, "Tlön, Uqbar, Orbis Tertius," trans. Andrew Hurley, in Collected Fictions (London: Penguin Books, 1999/1998), pp. 68-81, at p. 77. "La crítica suele inventar autores: elige dos obras disímiles - el Tao Te King y las 1001 Noches, digamos -, las atribuye a un mismo escritor y luego determina 
con probidad la psicología de ese interesante homme de lettres..." (Borges, "Tlön, Uqbar, Orbis Tertius," in Ficciones (Madrid: Alianza Editorial, 2000/1941), pp. 13-40, at p. 31).

2. A terminological clarification is in place here. Fiction and literature are different concepts: fiction refers to the author's mode of utterance (the utterance is intended to be imagined or made-believe by the readers), whereas literature is an evaluative term (the work is intended and/or considered to offer aesthetically valuable experience). A work of literature does not need to be fictional, and a fiction might not count as literature. In this paper, I shall focus on literary fictions, that is, works of imaginative literature that are intended and/or considered to offer aesthetically valuable experience. In general, both my terms fiction and literature will elliptically refer to this class of works, if not otherwise restricted or emphasized.

3. Wayne C. Booth, The Rhetoric of Fiction, second ed. (Chicago: The University of Chicago Press, 1983/1961), pp. 74-75. Booth says that before him, the implied author has been called, for instance, the author's second self by Kathleen Tillotson (see Tillotson, The Tale and the Teller: A Lecture on the Place of the Narrator in Fiction (London: Hart-Davis, 1959), p. 22). In turn, John Killham (in Killham, "The 'Second Self' in Novel Criticism," British Journal of Aesthetics 6, no. 3 (1966), pp. 272-290, at p. 275) suggests that the term the author's second self was already used by Edward Dowden in his work Studies in Literature 1789-1877 (1877, p. 240).

4. See also Tom Kindt and Hans-Harald Müller, The Implied Author: Concept and Controversy, trans. Alastair Matthews (New York: Walter de Gruyter, 2006), p. 8.

5. Wayne C. Booth, The Rhetoric of Fiction, pp. 74-75.

6. Ibid., pp. 71-73.

7. Wayne C. Booth, The Company We Keep: An Ethics of Fiction (Berkeley: University of California Press, 1988), p. 150.

8. It is generally thought that hypothetical intentionalism was first introduced by William E. Tolhurst (see Tolhurst, "On What a Text is and How it Means," British Journal of Aesthetics 19, no. 1 (1979), pp. 3-14, at pp. 3-4, 8 and 11-12). The interpretative practice was baptized by Jerrold Levinson who has developed Tolhurst's account in his studies (see Levinson, "Intention and Interpretation: A Last Look," in Intention and Interpretation, ed. Gary Iseminger (Philadelphia: Temple University Press, 1992), pp. 221-256, at pp. 224-225 and 228-229; see also Levinson, "Interpretation and Intention in Literature," in The Pleasures of Aesthetics: Philosophical Essays (Ithaca: Cornell University Press, 1996), pp. 175213, at pp. 178-179, 184 and 198, and Levinson, "Hypothetical Intentionalism: Statement, Objections, and Replies," in Is There a Single Right Interpretation?, ed. Michael Krausz (Pennsylvania: Pennsylvania State University Press, 2002), pp. 309-318, at pp. 309 and 317). 
9. Alexander Nehamas, "Writer, Text, Work, Author," in The Death and Resurrection of the Author?, ed. William Irwin (Westport: Greenwood Press, 2002), pp. 95116, at p. 101 (originally published in Literature and the Question of Philosophy, ed. A. J. Cascardi (Baltimore: Johns Hopkins University Press, 1987), pp. 267-291). 10. Alexander Nehamas, "The Postulated Author: Critical Monism as a Regulative Ideal," Critical Inquiry 8, no. 1 (1981), pp. 133-149, at p. 145.

11. Alexander Nehamas, "What an Author is?" The Journal of Philosophy 83, no. 11 (1986), pp. 685-691, at pp. 689 and 690.

12. Jenefer M. Robinson, "Style and Personality in the Literary Work," The Philosophical Review 94, no. 2 (1985), pp. 227-247, at pp. 227, 229, 231 and 235. Like Booth, Robinson also thinks that the implied author's style is, at least to some extent, bound to an individual work. Here, see also Robinson, "General and Individual Style in Literature," Journal of Aesthetics and Art Criticism 43, no. 2 (1984), pp. $147-158$.

13. See P. D. Juhl, Interpretation. An Essay in the Philosophy of Literary Criticism (Princeton: Princeton University Press, 1986/1976), p. 192.

14. Nonetheless, although Austinian/Searlean and Gricean based anti-cognitivist views consider fictions utterances aimed for readers to imagine or make-believe, many anti-cognitivists admit that authors make direct and indirect assertions in their works. More like, they emphasize that the author's direct assertions should be considered rather part of the fictional story and that the indirect assertions are difficult for readers to locate, identify and paraphrase.

15. Joseph Margolis, Art and Philosophy (Brighton: The Harvester Press, 1980), p. 272.

16. See Noël Carroll, "Art, Intentions, and Conversation," in Intention and Interpretation, ed. G. Iseminger, pp. 97-131, at p. 97 and Carroll, "Interpretation and Intention: The Debate between Hypothetical and Actual Intentionalism," in Beyond Aesthetics: Philosophical Essays (Cambridge: Cambridge University Press, 2001), pp. 197-213, at p. 202 (originally published in Metaphilosophy 31, nos. 1-2 (2000), pp. 75-95). See also Paisley Livingston's critique of Carroll's view (in Livingston, Art and Intention: A Philosophical Study. (Oxford: Clarendon Press, 2005), pp. 150-151) and Carroll's response to Livingston (in Carroll, "Art, Mind, and Intention," Philosophy of Literature 31, no. 2 (2007), pp. 394-404, at p. 404, footnote no. 4).

17. Carroll, "Art, Intentions, and Conversation," 110; see also Carroll, "The Intentional Fallacy: Defending Myself," Journal of Aesthetics and Art Criticism 55, no. 3 (1997), pp. 305-309, at p. 306.

18. See Levinson, “Intention and Interpretation: A Last Look," pp. 245-246.

19. Here, see P. D. Juhl, Interpretation, p. 13; Richard Wollheim, Art and Its Objects, second ed. (Cambridge: Cambridge University Press, 1980), pp. 190-191.

20. Gregory Currie, The Nature of Fiction (Cambridge: Cambridge University 
Press, 1990), pp. 76 and 78. While the actual author and the implied author are distinct entities, Currie (ibid, p. 78) suggests that it is quite likely that the personality of the implied author depends "some way or other on the kind of person the real author is." For example, Currie says that one may assume that the actual author and the fictional author belong to the same community, period and place.

21. See Carroll, "Art, Intentions, and Conversation," pp. 100-101; Carroll, "AngloAmerican and Contemporary Criticism: Intention and the Hermeneutics of Suspicion," Journal of Aesthetics and Art Criticism 51, no. 2 (1993), pp. 245-252, at p. 251; Carroll, "The Intentional Fallacy: Defending Myself," p. 308; Carroll, "Interpretation and Intention: The Debate between Hypothetical and Actual Intentionalism," pp. 197-198 and 200-201. See also Richard Wollheim, Painting as an Art (Princeton: Princeton University Press, 1987), p. 44 and Livingston, Art and Intention, pp. 47-48 and 165-169, for perspicacious accounts on the complexity of mental events and artistic creation and the aims of moderate intentionalist interpretation of art.

22. Daniel O. Nathan, "Irony and the Artist's Intentions," British Journal of Aesthetics 22, no. 3 (1982), pp. 245-256, at pp. 247 and 249-251; see also Robert Stecker, Artworks: Definition, Meaning, Value (University Park: Pennsylvania State University Press, 1997), p. 189.

23. Nehamas, "The Postulated Author: Critical Monism as a Regulative Ideal," p. 147.

24. See Stecker, Artworks, pp. 188-189; Stecker, "Apparent, Implied, and Postulated Authors," in The Death and Resurrection of the Author?, ed. William Irwin pp. 129-140, at p. 134 (originally published in Philosophy and Literature 11, no. 2 (1987), pp. 258-271). Many literary critics also admit that the distinction between the actual author and the implied author is often arbitrary (see e.g. James Phelan, Living to Tell about it: A Rhetoric and Ethics of Narration (Ithaca: Cornell University Press, 2005), p. 7; Phelan, "Estranging Unreliability, Bonding Unreliability, and the Ethics of Lolita," Narrative 15, no. 2 (2007), pp. 222-238, at p. 224). In turn, it has also been argued that every sort of textual interpretation projects an author construct. William Irwin, an actual intentionalist, argues that actual intentionalists also need an author construct, which he calls "the urauthor," because actual intentionalism cannot ever reach "the real historical author." For Irwin, the urauthor is a mental construct generated by the reader from the text, "relevant biographical information" of the author, her other works, information about her contemporary literary culture and the like. (Irwin, Intentionalist Interpretation: A Philosophical Explanation and Defense (Westport: Greenwood Press, 1999), pp. 30-33 and 61-64). As he sees it, readers always have "a more or less accurate version" of the real historical author "as related to his text, an author construct" (Irwin, "Intentionalism and Author Constructs," in The Death and Resurrection of 
the Author?, ed. by Irwin, pp. 191-204, at p. 193). For Irwin, urinterpretation, a development of Hirsch's intentionalist interpretation, is interpretation that "seeks to capture the intention of the author, though not necessarily his understanding." According to him, "urinterpretation is not necessarily the original interpretation of the text, but rather the interpretation made in accord with the original meaning of the author, as he intended to communicate it." Moreover, Irwin argues that the author "may not fully understand his text, and neither may his contemporaries, and so recapturing his or their understanding is not always worthwhile. Inasmuch as the author's text is an intentional effort to communicate, however, his intention is indeed worth recapturing." (Irwin, Intentionalist Interpretation, pp. 11-12). Here, I disagree with Irwin, although the disagreement is to a large degree terminological: I prefer speaking about interpretations or hypotheses or assumptions of the actual author's intended meaning, whereas Irwin would call these interpretations "author constructs." As I see it, the interpreter may reach the historical author as she, for example, recognizes the meaning the historical author intended for her work. However, because the historical author's declarations of intention, for instance, are also subject to interpretation - after all, declarations are statements about intentions -, the interpreter cannot always confirm her assumption about the author's actual intention.

25. Saam Trivedi, "An Epistemic Dilemma for Actual Intentionalism," British Journal of Aesthetics 41, no. 2 (2001), pp. 192-206, at p. 202. As Trivedi notes, if one is to take artworks as communication, it might "call for emphasizing their status as products of real human agents, namely actual artists, not fictional or hypothetical artists."

26. See Livingston, Art and Intention, p. 165; Sherri Irvin, "Authors, Intentions, and Literary Meaning," Philosophy Compass 1, no. 2 (2006), pp. 114-128, at p. 123. The terms actual author hypothetical intentionalism and postulated author hypothetical intentionalism are adopted from Irvin's article. Livingston, in turn, uses the terms hypothetical intentionalism and fictional intentionalism.

27. For a hypothetical intentionalist account of "messages through fiction" issue, see Jerrold Levinson, "Messages in Art," in The Pleasures of Aesthetics: Philosophical Essays (Ithaca: Cornell University Press, 1996), pp. 224-241.

28. The distinction between the meaning given by the actual author and the significance given by a reader has been made by E. D. Hirsch Jr. in his insightful study Validity of Interpretation (Hirsch, Validity in Interpretation (New Haven: Yale University Press, 1967), p. 8).

29. See Levinson, "Intention and Interpretation: A Last Look," pp. 224-225 and 227-228.

30. Naturally, these practices may be, and often are, conjoined; sometimes it may also be difficult to say whether an interpretation is anachronistic or not. 
31. See Uri Margolin, "Cognitive Science, the Thinking Mind, and Literary Narrative," in Narrative Theory and the Cognitive Sciences, ed. David Herman (Stanford: Stanford University Center for the Study of Language and Information, 2003), pp. 271-294, at pp. 276-277.

32. See Wayne C. Booth, "Resurrection of the Implied Author: Why Bother?" in A Companion to Narrative Theory, ed. James Phelan and Peter J. Rabinowitz (Malden: Blackwell, 2005), pp. 75-88, at pp. 76-79 and 86.

33. Already in The Rhetoric of Fiction, Booth says that in the history of literary criticism the implied author has been referred to as the author's style.

34. Instead of saying that the actual author creates an implied author, one might speak about the author as how she appears or manifests herself in her work. Kendall Walton, for one, notes that style describes actions, not objects. As Walton sees it, to attribute a style to a work of literary fiction involves speaking about the act of creating the object, and works appear to be results of intentional acts. Walton notes that in literature, for instance, the nature of the decisions the author apparently made about how the work was to be is important, for these decisions seem to have been motivated by certain beliefs or aimed at certain goals. According to Walton, one can say that the artist acted with certain intentions in writing her work. Hence, Walton suggests that one should speak of the artist as she appears in the work or of the "apparent artist." (Kendall L. Walton, "Style and the Products and Processes of Art," in The Concept of Style, ed. Berel Lang (Philadelphia: University of Pennsylvania Press, 1987/1979), pp. 73-103, at pp. 73, 81, 84 and 93). Likewise, Berys Gaut (in Gaut, Art, Emotion and Ethics (Oxford: Oxford University Press, 2007, p. 72), leaning on Guy Sircello's view of artistic acts, speaks of "the manifested artist," who is "ascribed the qualities that are possessed by the artistic acts performed in the work." Gaut argues that the author, as the flesh-and-blood author and as the author of a literary fiction, does not consist of two different men, or actual and fictional individuals, but different persona of the same actual man or woman (ibid., 73-76).

35. Simone de Beauvoir, "Mon expérience d'écrivain," in Les écrits de Simone de Beauvoir, ed. Claude Francis and Fernande Gontier (Paris: Gallimard, 1979), pp. 439-457, at p. 442 (the lecture was given in Japan, September 1966). 